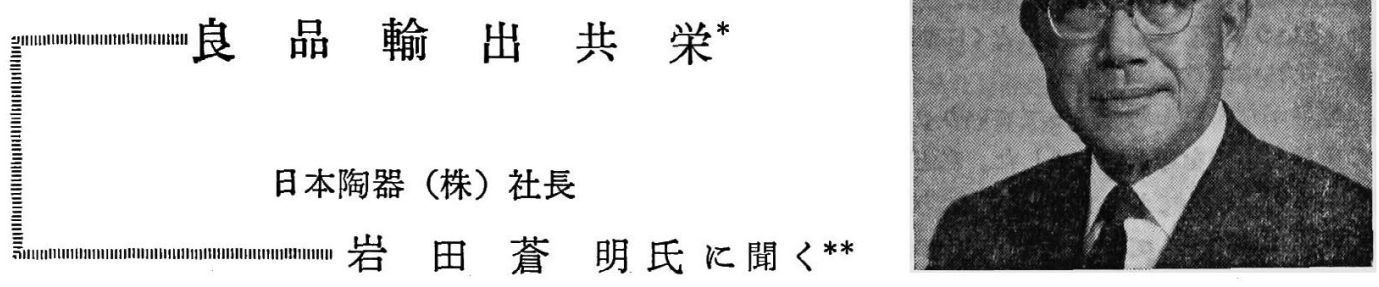

一明治時代にわが国で初めて洋風ディナーセットの工業化に 成功され，その後これを世界の第一級品にまで“Noritake China” として名声を高められたわけでこざいますが，その間 のご苦心談をお伺いいたしたいと存じます。

これはやはり時勢に先がけて，その当時としては常に 工場の近代化に心がけてきた賜物たと思いますね。昔は 䒜で焚いていたものを，石炭の炭割一一倒焰式丸䇺に変 えた。それが 28 本の煙突からもうもらと黒煙がでてい ましてね，私が会社に入社したとき，実はこんな会社で 働きたくないな，と思ったほどでした。これではいかん といらことで, ドイッからトンネルキルンを輸入し，さ らにこれを日本式焼成法を加味して改良しました。当時 高級陶磁器はトンネル割では焼けないるのだといら常識 がありましたが、この改良型のトンネル煮はここの常識 を打ら破って見事に成功致しました。

それからもら一つは調合の方法です。原料の調合は先 輩が苦労を重ねて一つの方法を決定したんですが，これ がディナーセットとして成功するもとであったよらに同 っております。ご承知のとおり陶磁器といらすのは, 成 形して焼成すると $10 \%$ 縮さといら一つの問題があるん です。均一性が要求されるディナーセットをいかに造り 出すかということで苦労したわけですが，ようやく坏土 の均質化の方法を生み出しました。それは deairing machine 一要するに空気を抜いて坏土の均一化をはか る方法なのです。さらに成形する際の密度の均一化をは かるために, ローラーマシンを開発しました。それから 菓燥の際の均質化。これにはジェット・ドライニンクと いらすのを導入しました。もら一つ焼成温度の均一化を はかるために，良熱伝導性の炭化理素質の䩗を開発しま した。

むら一つの問題として，当時の思潮でああったわけで すが, “輸出立国”ということを社是として堅持してい たわけです。つまり生きた企業というすのは，その企業 に培われている心が大切だといらことですね。われわれ

* 日本陶器 (株) の社是による。

**人闑手>白戸 紋平 (名古屋大学工学部教授 本会東海支部長) 隅田隆太郎（伯州大学織維学部教授 本会䋧集企画委員）

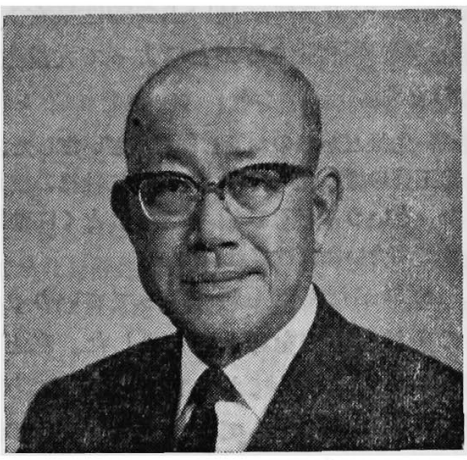

略 歴: 明治 36 年 3 月愛知県几生まれる。大正 15 年 3 月東 京商科大学専門部卒業後，日本陶器 (株) 飞入社。昭和 19 年 12 月取締役就任, 20 年 5 月常務取締役, 25 年 1 月専務取締役, 31 年 7 月副社長, 36 年 1 月取締役社長汇就任し，現在に至る。そ の他多数の会社会長，社長，取締役を兼任するとともに，中部 経済連合会副会長, 日経連常任理事, 経団連理事, 名古屋商工 会議所常議員等を併任。藍綬偯賞授賞。趣味: ゴルフ。

も良品主義に徹するということでやってまいりました か，終戦当時原料も悪いし 熟練工もいないということ で，わずかに色の黑い、陶磁器ができた時代がございまし た。これを当時 “ローズ・チャイナ”と称して, 決して “ノリタケ・チャイナ”とはしなかった。昔のような立 派な製品ができるようになるまで“ノリタケ”の名を污 したくないといら気持があったのです。こらいった良品 主義に徹する気持が，“ノリタヶ・チャイナ”を世界の 一級品にまで育てあげた大きな理由ではなからうかと思 っております。

今日私どるが世界的な特許をとって扣ります“Progression China”一一耐熱強化磁器と称しておりますよ らなものをつくるまでに育ててくることができましたの も，こういった永年培われた精神があのをいったのでは ないかと思っております。

一一陶磁器の高い芸術性と工業的な大量生産とはなにか相反す る条件のように思われますが，これをどのようにうまく両立さ せておられるのでしょうか。

私どもの製品は実用性，合目的性をもつ一方，日常生 活に潤いと豊かさを与えるるのとして，工芸的価値の高 いもの一こご質問の芸術性をこう称したいと思いますが 一た゚と思っております。私どるはこの工芸性と工業的 大量生産とは相反するものではなく，立派に両立するも のだ思っております。魅力あるよい意质を作る，それ を大量生産でやっていこうとする場合に，できるだけこ れを分析して，単一の仕事に細分化してしまうわけて す。数人あるいは数 10 人の人がそれぞれ一番簡単な仕 事をやって，完成したデザインを作っていく—SK 方 法をとっていく，こういうことをうちではやっておりま 
す。このように, 高い工芸的性格をもつものでも, 分業 をらまく活用することによって大量生産は立派になりた ちます。

一先ほどからのお話しにあございましたように，罂磁器の製 造工程の譏械化・自動化のために独得の技術を数多く開発され た，ということでございますが，とくに効果の大きかったすの をご紹介いただけませんか。

原料がたんだん悪くなってまいりましたときに，原料 の脱鉄の方法を考え出しました。私どもは天草石の最す よいるのを使っておりましたが，こういった良質の原料 がしたいに枯渴してきますと，鉄粉のかなりある二級品 を使わねばならなくなりました。そこで熊本大学などに 依頼したりして，いろいろ脱鉄の方法を考光て開発しま した脱鉄機がございます。これは特許をとっております。 それから成形機ですね。私どもは先ほどお話しした口 ーラーマシンおよびさらに高性能の自動成形機を考案し まして現在三好工場で立派に稼動しております。

つぎに，少し小さいるのになりますが,コーヒー茶碗 を私どもはふせ焼きでやっておりますので，ふちずりを らまくやらなければなりません。このため自動ふらずり 機を考案して美事にきれいなふらずりが行なわれており ます。これは研磨紙布を巧みに利用した方法をとり入れ たわけです。

つぎにトンネル篤です。さきほど申しましたようにド イッから輸入したのですが、これを陶磁器が均一に焼け るよらに改良いたしました。それからこのトンネル鴳を 基礎として研削砥石を焼成するトンネル案の開発もしま した。ドイッではうまく狫けなかったものを，私どもが 改良して設計を教えてあげました。

一最近の陶磁器の流行はいかがなものでしょうか。また新し いデザインの開発はどのようにしておられますでしょうか。

しだいに大変カラフルなるのがフメリカでは流行して おります。私どすはシックで上品な絵柄をつけることを モットーにしてまいりましたが，やはり時勢の流れで， ストーンカラーでカラフルなるの, ストーンウェアに切 りかえつつあります。

またデザインの開発については，立派なデザイナーを 6名ほどアメリカに出して捕ります。また国内の販売会 社に市場調查ということで 7 名, 社内に約 30 名のデザ イナー, 30 名の助手, しめて 60 名ほどおります。こうい らデザイナーを使いまして新しいデザインの開発をして おります。ことにストーンウェアのむずかしいところ は，均一性ですね。1 個のすのですと素晴らしいものが できるのですが，12 個揃わないんですね。1 個なら 100 万円でも売れそうなものができるのですが，100枚つく ると全部違うというものもあるんです。まもなく磁器と 同しように完成すると思らのですが……

一話題が変りますが，わが国をとりまく国際的な経済情勢の 变化に伴いまして, 罂磁器はじめ各種の日本商品の輸出に暗い
影がさしはじめております。とくに対米輸出を中心とした今後 のわが国の輸出の動向について，経営者としてどのようにお考 えでしょうか。また，東南アジアの一部の国では現在日本商品 の排斥運動あるいは日本人のエコノミックアニマルの悪鲆が高 まっておりますが，こういった動きにどう对処していったらよ ろしいでしょうか。

これは明確に敃答えできると思いをす。（笑）この問 題について私どすは暗い影とは認めておりません。とい いますのは, 三菱総合研究所が先般アメリカでは何をす っとも輸入したかっっているかについて調査をやったので すが，まず第一番が道路走行車輛，そのつぎが通信機や ラシオ，テレビ，そして第三番目が陶磁器なんです。ご 存知のように, アメリカでは家庭用陶磁器メーカーはほ とんと倒産しておりまして，いま残って拈りますのはレ ノックス社とかフランシスカン社といった優良メーカー 4，5社だけです。ですから，アメリカとしては，陶磁 器の輸入は絶対必要なわけです。そういう意味で私どす は楽観をしております。

それからすら一つ，私どすはもら少し高度な考方方を しているんですが，いまアメリカで一番大手のメーカー とされているレノックスやフランシスカンが日本に進出 する機会を狙っているようなんですが，なかなか日本に は出られない。そこで私どもの方で卒先して, わが社の 販売網にかけてレノックス社の製品を売り出そらと考兄 て怙ります。こらいらこともおりまぜてアメリカとの関 係をらまくやっていけば, 陶磁器輸出に関する限り暗い 影はさしてこないと考えておりりす。

それから，いまタイ国あたりで日貨排斥云々という問 題が起きて扣りますが，私どすの品物に関してはそらい ら問題は起こって括りません。これはやはり相手国の事 情をよく知って，共存共栄の立場をとっていけばそれは どに日本商品の排斥をらけるようなことはないと思いま す。やはり輸出秩序の確立— - Ordery Marcketing の必 要性を痛感いたしております。

エュノミックアニマルの悪評につきししは, パキス タンのある外交官が日本の高度成長を㪨望して, 皮肉っ て1回だけしゃべった言葉なんです。アメリカです英国 でも日本人をエコノミックアニマルとはいっておりませ ん。日本人の方がジャーナリスチックに誇大に使ってい るんですね。日本人自身がそれを広げてしまうというい き方は慎しむべきたと思います。したがってこの問題は 悪評にとる必要はないと私は解釈しております。

一最近，諸外国へプラント輸出を橡極的に進めておられるよ うでございますが，外国との技術交流の将来についてどのよう にお考えでいらっしゅいますか。

私どもたたいまイランにプラント輸出をしまして，非 常によい製品がイランでできるようになって和ります。 来年あたりは第 2 次増設が実現するんじゃいかと思っ て扣ります。それからスリランカ(セイロン) に磁器の 
工場をいま建設中でございまして8 月末には完成の予定 でございます。

もともと私どもはブラント輸出については消極的な時 代もございました。しかし私どすの方が出ていきません と，英国やドイッが進出してきます。実はスリランカの 貿易公団の総裁がこられまして, 磁器がほしいのだが， リタヶの品質程度のるのができないだらか，といらこ とからブラント輸出をすることに決めたわけでごさいま す。多少原料の点に問題がありましたが，まあまあ一流 の品物が生産できる目具がついております。こういった 共存共栄の精神が私どもの会社の長い伝統と歴史となっ ております。新しく陶磁器の工場をつくるということは 発展途上国にとっては新しい産業ですから，非常に意欲 飞然えております。いま，スリランカから 6 7 名の研 修生が私のところに来ておりますが，大変真面目たし頭 も良い。私どもも優秀な技術者をむこうに派遗しており ますので, 必ずやこの新しい工場は成功するものと確信 しております。

\section{一昨今, 日本列虫改造諭が各方面で諭議されておりますが,} 財界人としてわが国の库業挷造をどのように改革すべきだとお 考えでございしょうか。とくに技術開発についてのご意見を お闆かせいただきたいと存じます。

なかなかむずかしい問題だと思います。私ども自体が 10 年後には法律で名古屋に打られないといらことにな ると，どこかへ出ていかなければなりません。しかし果 してそらいら必然があろらかといらことも問題がござい ます。なんとなれば産業構造を变えていかなる土地に出 ていこうとも，公害をもっていったのではなんにもなら んわけです。そういうことから私どすは環境保全装置の 技術開発にいま非常に力を入れております。たとえば焼 却炻一つにしましても, 新しい手法を入れて, スタティ ックミキサーでやりますとまあまあ完壁な焼却炉ができ 上がります。また水の沪過装置あるいは油の沪過装置な ども併せて考えて怙ります。

とにかく公害をるった企業というものは，公害を出さ ない態勢にしてから移るべきたと考えておりますがむ ずかしいですね。たとえば瀬戸，多治見へ行ってみます と，溜々と白い水が流れて打りますか，あれがきれいに ならなければ，それは無意味なことだと思いますね。産 業構造をいかにしゃべりましてる，あの土地は案業，つ まり陶磁器工業で生活しているところなんです。あの地 区がそれによって公害を生ずることなく，川の水がいっ もきれいで，魚が棲むといら状況にまでるっていかなけ ればならないと思いますね。やがてそらいう時期が，そ 510 年後にはくるんじゃないでしょらか。

もう一つつけ加えますと，出てしまった公害をどうに かすることに追われているのが現状なんですか，環境保
全といら以上に，自然を育成するといいますか，自然の 浄化能力をアップするといらような，そらいら技術開発 というすのがあるんじゃいでしょらか。まったく金に はなりませんが，そらいう問題も社会人の一人として考 えていかなければなりませんね。

最近のわが国の窑業各社は公害闌連機器とか弱電気部品, 建材など，事業の多角化を活発に進めておられますが，わが国 の等業産業は将来どのような方向へ進むべきだとお考えでしょ うか。

ご質問のとおりだと思います。私どすの会社ですいま 公害関連の仕事をやっておりますし, 弱電部品つまり電 子部品も手がけて拉りますし, 建材もさかんにやってお ります。むかしは一つの事業に打ちこむことがいいとい われたんですが，昨今ではそれではなかなかやっていけ ません。茶䛷一つでは私たちの生活はやっていけませ ん。否応なしに入ってきたといらことなんですね。

もっとも喜業製品といらすのの一つの特徵から申しま すと，耐熱あるいは耐酸，耐食，耐磨，電気絶縁性とい らことですから，近来の技術革新の一つの柱である材料 科学——テリアル・サイエンスに対応するために, こ ういう特性をるつ䇺業分野の進歩がな斿ればならないと 思います。宇宙工学とか原子力関係での急速の進歩に伴 って, ニューセラミックスがつぎつぎと開発されており ます。そういら方向に行く産業もごさいましょうし，産 業自体のあり方として，要は収益をあげねばなりません から，収益の上がるるのに自ら取り組んでいくより方法 がないんです。

私どすの企業の歴史からみて，嚑業一陶磁器を手はじ めに，その必要性から，優秀な研削砥石をつくった。そ の砥石をつくるために必要な機峨を考案する。それから システマチックアプローチから，一つのシステムにした 研削研石を考兑なければならなくなった。それには油る 必要ですからどういら油を使ったらいいか，といったシ ステマチックな仕事が派生してくるわけです。

私どもはアルミナの磁器もやっておりますから，その 基板から電子部品を一つやってみよらといらことにな る。われわれのところで転写印刷もやってお゙りますの で，直接印刷じなくして，間接印刷といら表裏いっぺ んに印刷する方法を一つ解決しょうということで電子部 品に乗り出した。そらすると厚膜プリント基板というる のか間接印刷法で完成したんです。これがたんたん発展 してきまして， 単なる厚膜 IC ではなくて，今度は高速 で特殊紙に印字できるサーマル・プリンターヘッドまで 完成しまして，いまこれが卓上計算器にどう応用される かという研究にまで進んで打ります。

(1973.1.9 文贵在記者) 